\title{
The Impact of Road Salts on Groundwater and Estimation of the Chlorine Ions by Hydrogen Index
}

\author{
Damira Sambaeva1, Janarbek Izakov², Timur Maymekov ${ }^{3}$ Kubat Kemelov ${ }^{2 *}$, \\ Nurzat Shaykieva ${ }^{2}$, Astra Ukeleeva ${ }^{4}$, Zarlyk Maymekov ${ }^{2}$ \\ ${ }^{1}$ Kyrgyz State University of Geology, Mining, and Natural Resources Development \\ Named after academician U. Asanaliev, Bishkek, Kyrgyz Republic \\ ${ }^{2}$ Department of Environmental Engineering, Kyrgyz-Turkish Manas University, Bishkek, Kyrgyz Republic \\ ${ }^{3}$ Moscow Institute of Physics and Technology, Dolgoprudny, Russia \\ ${ }^{4}$ Institute of Chemistry and Phytotechnology of the National Academy of Sciences of the Kyrgyz Republic,
}

Bishkek, Kyrgyz Republic

Received: 25 December 2020

Accepted: 17 August 2021

\begin{abstract}
In this study, the influence of road salts on groundwater was investigated. The use of anti-ice reagents in winter requires certain precautions since the main chemical composition of the salts is chlorides. At the same time, the widely used sodium chloride does not form ion pairs in water, which means that it has a high migration ability and a weak sorption potential. In addition, the concentration of chloride salts in the components of the environment is so high (10-140 ppm). Therefore, the rapid assessment of the concentration of technogenic chlorine ion in water by $\mathrm{pH}$ is an urgent task. The average chemical composition of groundwater in Bishkek and its environs was considered, and the concentration of chlorine ions in water from 72 wells was determined. To develop the pattern of dispersion of chlorine ions, the thermodynamic modeling of the sodium chloride-water system was carried out at a minimum of Gibbs energy with a wide range of water temperature changes corresponding to the flow regime of cold groundwater. The concentration distribution of the components, charged particles, as well as the values of $\mathrm{pH}$ and $\mathrm{Eh}$ were determined. As a result, an empirical equation and a scheme for rapid assessment of the quantitative content of chlorine ions in water bodies were compiled.
\end{abstract}

Keywords: sodium chloride, road salts, groundwater pollution, groundwater $\mathrm{pH}$, Bishkek 


\section{Introduction}

A mixture of chloride salts of alkaline $(\mathrm{NaCl})$ and alkaline earth metals $\left(\mathrm{CaCl}_{2}, \mathrm{MgCl}_{2}\right)$ is usually used to effectively dissolve snow and ice on urban transport roads in winter [1-2]. It should be noted here that the choice of deicing chemicals is very wide (Brands in the world: Ratmix, Aquays, Rockmelt, Ejik, Bionord, Greenride, Bischofite, Biomag, Icemelt power, Icemelt, Icemelt mix); they are produced both in solid and liquid form, depending on the technology of their application and production [3]. The unique properties of the above-mentioned modern deicing chemicals consist in a strictly dosed combination of salts used in winter conditions. Salts dissolve in water, and then, due to natural evaporation, are gradually dispersed in the surrounding natural environment, and part of the salt solutions seeps into groundwater. According to some literary sources, the concentration of chloride salts in waters located near transport roads, is 130-140 ppm [4]. The snow water from roadside zones has a higher mineralization (up to $3600 \mathrm{mg} / \mathrm{L}$ ) [5-8]. The concentration of salt components (chlorides - up to $2160 \mathrm{mg} / \mathrm{L}$, sodium - $355 \mathrm{mg} / \mathrm{L}$, Potassium - up to $225 \mathrm{mg} / \mathrm{L}$, calcium - up to $530 \mathrm{mg} / \mathrm{L}$, magnesium - up to $360 \mathrm{mg} / \mathrm{L}$ ) often exceed the threshold limit value (TLV) in water by 10-200 times. During the winter months, the concentration of chlorine ion $\left(\mathrm{Cl}^{-}\right)$in streams increased 20 times and ranged from 36 to $1350 \mathrm{mg} / \mathrm{L}$. The use of $23 \%$ of urban land for transport purposes increased the concentration of chlorine ions in river water by more than $150 \mathrm{mg} / \mathrm{L}$.

It has been noted that saline deicing agents lead to periodic changes in biogeochemical cycles in lake waters, including dissolved oxygen, $\mathrm{pH}$, and alkalinity. It is emphasized in [7] that the concentration of chlorides increases by more than $100 \mathrm{mg} / \mathrm{L}$, especially in most shallow $(<60 \mathrm{~m})$ public wells with groundwater, which strongly affects the chemical composition of watercourses and urban lakes. In the study of Mayer T. et al. (2008), a comprehensive study of the impact of road salts on the benthic compartment was carried out. The processes of exchange and transfer of $\mathrm{Na}^{+}$and $\mathrm{Cl}^{-}$ in the pond and their influence on the remobilization of heavy metals were evaluated. The salt reagents used are optimal in terms of efficiency, but at the same time have a negative impact on the environment [8].

Taking these circumstances into account, chloride salts used in winter conditions can be considered as potential loads influencing: changes in the biogeochemical water cycle [4]; salinization of drinking water [9-12]; degradation of aquatic life [13-15]; reduction of drinking water supplies [16-20]; on the processes of redox stratification of substances, including dissolved oxygen $[10,21]$; to increase the accumulation of methane and its release into the atmosphere [21]; toxicological effects on organisms of terrestrial and aquatic environments [22-29]. Accordingly, all deicing agents require certain precautions to be taken. In
Finland, salt is no longer used at temperatures below minus $5{ }^{\circ} \mathrm{C}$. Instead, sand and rock chips are used. In Austria and Sweden, fine sand in a ratio of 7:3 is mixed with hot water at a temperature of $90-95^{\circ} \mathrm{C}$ and sprayed on the streets. Hot sand melts into snow and makes the surface rough [13]. Iceland uses geothermal energy to heat the road. In Germany, the law permits the use of salt only on hazardous road sections. Baumgartel S. et al (2020), suggested groundwater heating to keep the road temperature above $0^{\circ} \mathrm{C}$ [30]. USA, Canada use magnesium chloride, which contains less chlorine than other chlorides $[4,6]$. In the study of Terry L.G. et al (2020), alternative deicing agents such as agro-based products, formates, succinates, acetates, and glycols were proposed instead of using traditional chloride salts [31].

Thus, the above-mentioned problems are discussed in many regions of the world. Nevertheless, the study of the effect of the chloride ion of salts on the distribution of the concentrations of cations, anions, and dissolved gases in the water itself remains open. This situation is extremely relevant for cities where nearby groundwater is used as a source of drinking water [32-34]. Taking these provisions into account, the goal was formulated: to study the effect of road salts on the components of groundwater and rapid assessment of the content of chlorine ions based on the $\mathrm{pH}$ of an aqueous solution. Research objectives were: determination of the technogenic load of sodium chloride used in winter on transport roads in Bishkek; compilation of a chemical matrix of groundwater based on samples from 72 wells of Bishkek and its environs, as the main source of the water supply in Bishkek [35-38]; determination of the concentration distribution of cations, anions and dissolved gases in the sodium chloride- water system at different temperatures; study of the effect of chlorine ion on the components of the water itself; obtaining an empirical equation for the rapid assessment of the concentration of chlorine ion in wastewater based on the $\mathrm{pH}$ of the solution.

\section{Material and Methods}

Municipal company "Tazalyk" of Bishkek city performs deicing work with such materials as sand and salt in winter. The preparation of a mixture of salt and sand is carried out at three bases located on Rostovskaya 19b, Ala-Archinskaya 74, Severnaya 31A streets in Bishkek. Sand to "Tazalyk" is supplied by the public limited company (LLC) "Kum-Shagyl" and salt from "Kaz Tuz Trans" LLC. According to the city's municipal construction department, the total length of roads in Bishkek is $31,200 \mathrm{~km}$. The municipal company "Tazalyk" uses 2184 tons of salt and 29016 tons of sand in winter. Consumption rate of sand and sandsalt mixture is $200-300 \mathrm{~g} / \mathrm{m}^{2}$, chlorides are $20-40 \mathrm{~g} / \mathrm{m}^{2}$. The total demand for the mixture is 8646.9 tons, of which sand is $93 \%$ (8042 tons); salt - 7\% (605 tons). 
A sand-salt mixture is obtained by mixing sand with sodium chloride or calcium chloride in a ratio of $92-97 \%$ sand and $3-8 \%$ reagents. The required amount of salt is determined on a dry matter basis. For the preparation of the sand-salt mixture per $1000 \mathrm{~m}^{2}$ area, $4-8 \mathrm{~m}^{3}$ of sand is used per $1 \mathrm{~m}^{3}$ of chlorides. They are stored in special containers [39]. Anti-icing agents dissolve snow (ice) dwell, but due to non-observance of the optimal ratio of salts and sand, they can penetrate into underground horizons, at the same time harming the environment, especially in the water supply system of Bishkek. Taking into account the above circumstances, the content of the chlorine ion in water were investigated by the hydrogen index $(\mathrm{pH})$. Samples were collected from 72 wells in and around Bishkek, Kyrgyzstan, and the $\mathrm{pH}$ values were measured using a $\mathrm{pH}$ meter (Mettler Toledo, USA). Below is a schematic map of the location of individual wells (Fig. 1) [36-38].

Accordingly, the physicochemical modeling of the $\mathrm{NaCl}-\mathrm{H}_{2} \mathrm{O}$ system was carried out with a wide variation in the content of chlorine-ions by minimization of the isobaric-isothermal potential (Gibbs energy). The calculations were carried out using the "Selector" software. The software works based on the Gibbs free energy minimization method and is widely used in world scientific research (Russia, Irkutsk, Karpov; Moscow State University, Shvarov, Rafalski, Galimzyanov; Paul Scherrer Swiss Institute; German universities in Bayreuth, Hanover) [40-41]. The advantages of the method include the possibility of combining the models of dynamics and mass transfer into a system consisting of reservoirs directly and inversely connected with each other and with the environment through flows of matter and energy. In other words, the combination and coordination of the methods of equilibrium thermodynamics with the kinetics and dynamics of physicochemical processes were realized. At the same time, the methodological basis for modeling hydrogeological processes is the provision on the existence of partial and local equilibria. It should be noted that the water-sodium chloride system is usually not in equilibrium. However, the principle of local equilibrium was observed concerning an aqueous solution, components dissolved in it and minerals precipitated from it. Here, the most important factor that allows a non-equilibrium system to approach the state of chemical equilibrium is the rate of movement of groundwater, which regulates the emergence and maintenance of a chemical potential gradient in the system. Groundwater is a complex multicomponent system, the chemical elements in it are mainly not in the form of simple cations and anions, but in the form of complex associated compounds with different stability. Taking into account the above circumstances, independent and dependent components were the initial information for calculating the equilibrium state of the water-sodium chloride system, i.e. all forms of the compounds of independent components, potentially existing in the range of temperatures and pressures, wherein the simulation was performed. At the same time, the original thermodynamic properties of chemicals ( $\mathrm{G}, \mathrm{H}, \mathrm{S}, \mathrm{Cp}, \mathrm{C}, \mathrm{V})$ were obtained from widely validated standard thermodynamic databases [41].

In calculations the range of temperature variation of an aqueous solution of salts was set from 278.1 to $308.15 \mathrm{~K}$. The average elemental compositions of groundwater from 72 wells (in moles) were taken into

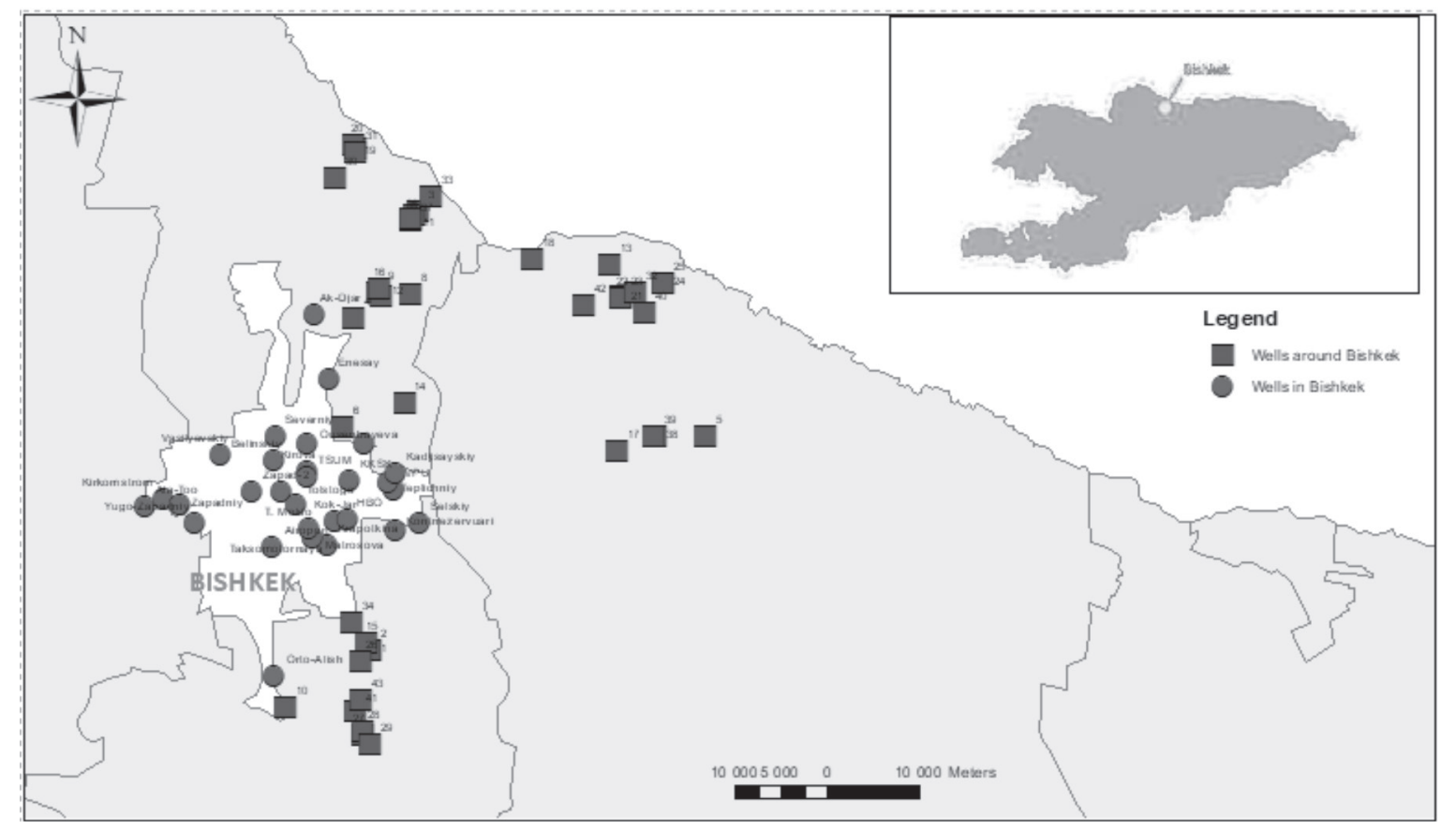

Fig. 1. Map of samples taken to determine the physicochemical parameters of water (wells). 


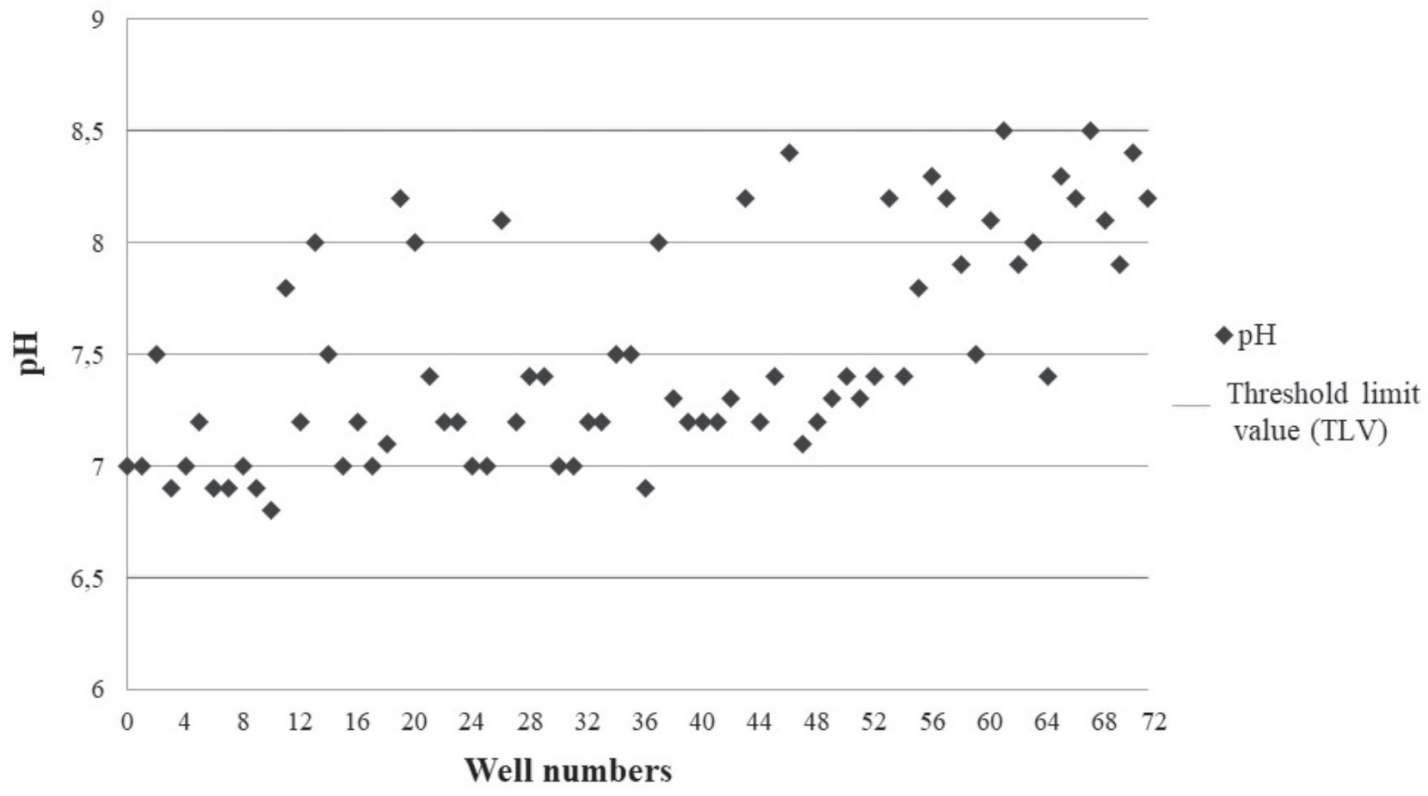

Fig. 2. The $\mathrm{pH}$ value of 72 groundwater wells in Bishkek and its environs.

account: $\mathrm{Na}(0.00179), \mathrm{Ca}(0.00107), \mathrm{Mg}(0.00055), \mathrm{C}$ (0.00251), $\mathrm{Cl}$ (0.00068), S (0.00085), N (0.00016), K (0.00006), H (111.02), O (55.52). The thermodynamic parameters of the initial components and their possible compounds in individual phases (gas, liquid, solid) were determined, and the concentration distributions of components, particles, and dissolved gases in solution were calculated. In addition, formulas for calculating $\mathrm{pH}$ were obtained. The experimental and calculated $\mathrm{pH}$ values are in satisfactory agreement. The relative error does not exceed $5 \%$.

\section{Results and Discussion}

The study of the direct effect of the chlorine ion on water components and the environment remains open. The concentration can change rapidly and a quick assessment of the chloride ion is required. In this study, a rapid assessment of the concentration of the technogenic chlorine ion in the water of reservoirs by the $\mathrm{pH}$ of the solution was carried out. For this purpose, the model system $\mathrm{NaCl}-\mathrm{H}_{2} \mathrm{O}$ was first considered at various concentrations of the technogenic chlorine ion (34.2-1000 $\mathrm{mg} / \mathrm{L})$ and water temperatures
(278.1-308.15 K). The chemical matrix of the studied groundwater included $(\mathrm{mg} / \mathrm{L}): \mathrm{Na}^{+}=41.24 ; \mathrm{K}^{+}=2.18$; $\mathrm{Ca}^{+2}=42.91 ; \mathrm{Mg}^{+2}=13.9 ; \mathrm{NH}_{4}^{+}=0,11 ; \mathrm{HCO}_{3}^{-}=152.9$; $\mathrm{Cl}^{-}=24.26 ; \mathrm{SO}_{4}^{2-}=81.3 ; \mathrm{NO}_{3}^{-}=8.91 ; \mathrm{NO}_{2}^{-}=0.39 ;$ initial salinity of water $\mathrm{S}=367.34 \mathrm{mg} / \mathrm{L}$. The average experimental value of groundwater $\mathrm{pH}$ in 72 wells was 7.7. (Fig. 2). This value correlates very well with the calculated value of $7.27(\mathrm{pH})$ at $278.15 \mathrm{~K}$ (Table 1).

Physicochemical and thermodynamic data (volume, mass, density, heat capacity, redox potential, hydrogen index, ionic strength, number of dissolved substances, Gibbs energy, enthalpy, entropy, internal energy) of the studied $\mathrm{NaCl}-\mathrm{H}_{2} \mathrm{O}$ system at $278.15 \mathrm{~K}$ are given in Table 1.

In this table, the values of total enthalpy $(\Delta \mathrm{H}<0)$ and internal energy $(\Delta U<0)$ are negative, which means that the process of dissolution of salts in water $(\Delta \mathrm{H}=-15.95 \mathrm{MJ} / \mathrm{kg}$; water salinity by sodium chloride was $\mathrm{S}=362.6 \mathrm{mg} / \mathrm{L}$ ). The deicing agent absorbs moisture from the external environment; heat is released as a result of the reaction $(\Delta \mathrm{H}<0)$; synergy between moisture and heat leads to the dissolution of snow and melting of ice. The dissolution of the solid phase is also associated with a change in the value of the redox potential (Eh), as well as the $\mathrm{pH}$ of the $\mathrm{NaCl}$ -

Table 1. Physicochemical and thermodynamic parameters of the system $\mathrm{NaCl}-\mathrm{H}_{2} \mathrm{O}$ at $278.15 \mathrm{~K}, \mathrm{Cl}=24.26 \mathrm{mg} / \mathrm{L}(0.00068 \mathrm{~mol})$.

\begin{tabular}{|c|c|c|c|c|c|}
\hline Temperature. K & 278.15 & $G, M J$ & -13.09 & $E h, V$ & 0.81 \\
\hline Pressure, $\mathrm{MPa}$ & 0.1 & $H, M J$ & -15.95 & - & - \\
\hline Volume, $\mathrm{m}^{3}$ & 0.00103 & $S, \mathrm{~kJ} / \mathrm{K}$ & 3.59 & $p H$ & 7.27 \\
\hline Weight, $\mathrm{kg}$ & 1 & $U, M J$ & -15.75 & $I$ & 0.004 \\
\hline Density, $\mathrm{kg} / \mathrm{m}^{3}$ & 971.84 & $C p . \mathrm{kJ}$ & 4.19 & $T D S . \mathrm{mg} / \mathrm{kg}$ & 183.5 \\
\hline
\end{tabular}




$$
1,4
$$

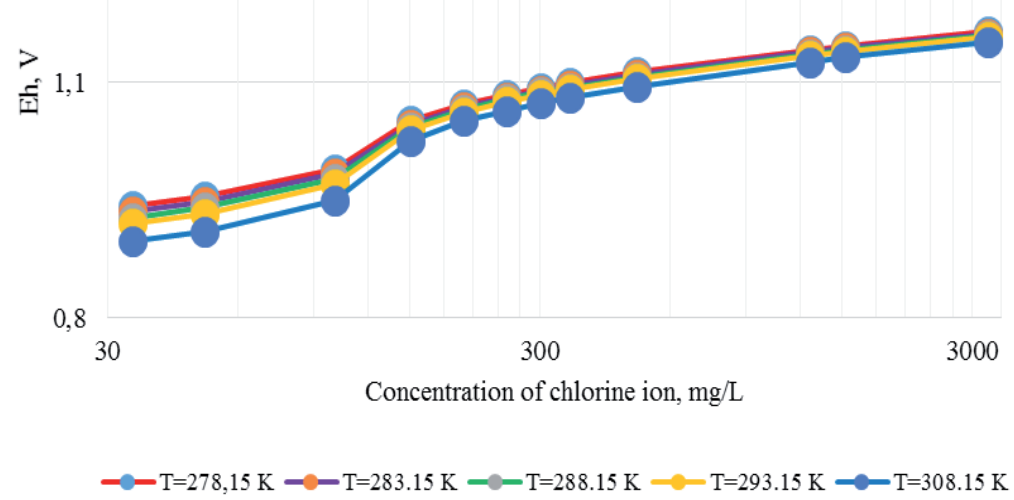

Fig. 3. Change in the value of the redox potential of the $\mathrm{NaCl}_{-}-\mathrm{H}_{2} \mathrm{O}$ system depending on the concentration of chlorine ion.

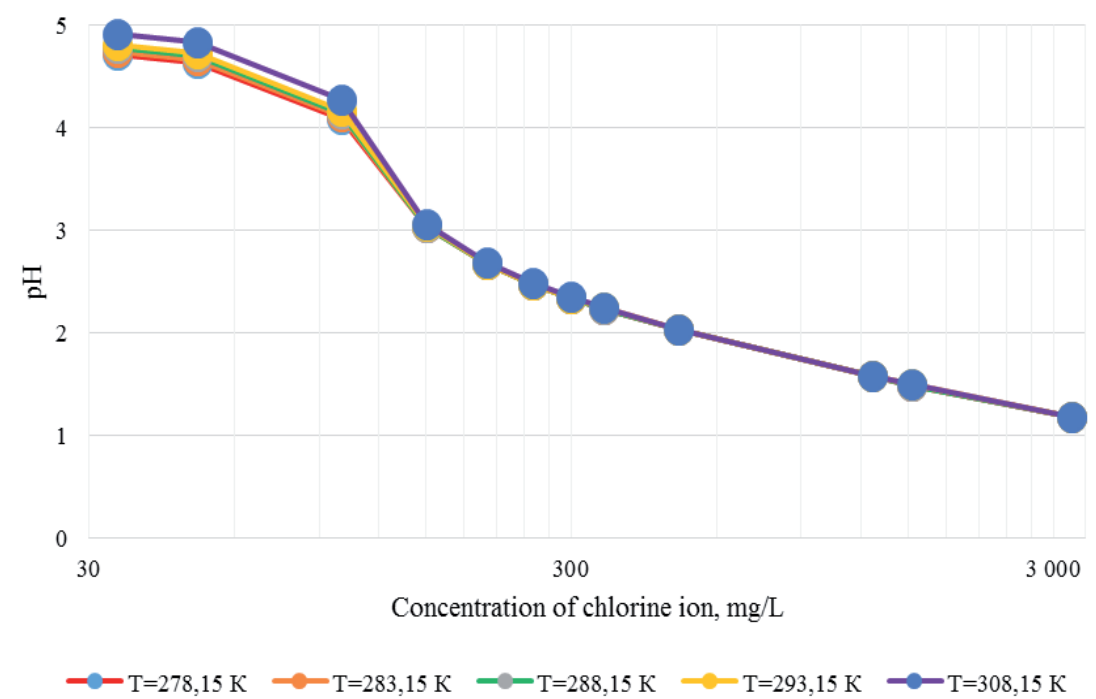

Fig. 4. Change in the $\mathrm{pH}$ value of the $\mathrm{NaCl}-\mathrm{H}_{2} \mathrm{O}$ system depending on the concentration of the technogenic chlorine ion.

$\mathrm{H}_{2} \mathrm{O}$ system at different concentrations of the chlorine ion in the solution (Figs 3 and 4).

The redox potential of the sodium chloride-water system was calculated and the following equations were obtained:

$278.15 \mathrm{~K}, \quad \mathrm{Eh}=0.0268 \ln \left(\mathrm{C}_{\mathrm{Cl}}\right)+0.9158$, $\mathrm{R}^{2}=0.8592 ; 283.15 \mathrm{~K}, \mathrm{Eh}=0.0274 \ln \left(\mathrm{C}_{\mathrm{Cl}}\right)+0.9087$, $\mathrm{R}^{2}=0.8575 ; 288.15 \mathrm{~K}, \mathrm{Eh}=0.028 \quad \ln \left(\mathrm{C}_{\mathrm{Cl}}\right)+0.9014$, $\mathrm{R}^{2}=0.8556 ; 293.15 \mathrm{~K}, \mathrm{E}=0.0285 \ln \left(\mathrm{C}_{\mathrm{Cl}}\right)+0.8941$, $\mathrm{R}^{2}=0.8533 ; 308.15 \mathrm{~K}, \mathrm{Eh}=0.0307 \ln \left(\mathrm{C}_{\mathrm{Cl}}\right)+0.869$, $\mathrm{R}^{2}=0.852$ (Fig. 3).

The calculation formulas for the $\mathrm{pH}$ of the solution were obtained (Fig. 4, Table 5):

$278.15 \mathrm{~K}, \quad \mathrm{pH}=24.178 \cdot \mathrm{C}_{\mathrm{Cl}}^{-0.401}, \quad \mathrm{R}^{2}=0.988$; $283.15 \mathrm{~K}, \mathrm{pH}=24,716 \cdot \mathrm{C}_{\mathrm{Cl}}{ }^{-0.405}, \mathrm{R}^{2}=0.9872 ; 288.15 \mathrm{~K}$, $\mathrm{pH}=25.15 \cdot \mathrm{C}_{\mathrm{Cl}}{ }^{-0.407}, \quad \mathrm{R}^{2}=0.9866 ; 293.15 \mathrm{~K}$, $\mathrm{pH}=25.557 \cdot \mathrm{C}_{\mathrm{Cl}}{ }^{-0.41}, \quad \mathrm{R}^{2}=0.9861 ; 308.15 \mathrm{~K}$, $\mathrm{pH}=41.839 \cdot \mathrm{C}_{\mathrm{Cl}}{ }^{-0.49}, \quad \mathrm{R}^{2}=0.9658 ;$ in general form: $\mathrm{pH}=29.17 \cdot \mathrm{C}_{\mathrm{Cl}}^{-0.44}$ (increase in the concentration of chlorine ion in water, $\mathrm{mg} / \mathrm{L}$ ), $\mathrm{pH}=8.49 \cdot \mathrm{C}_{\mathrm{Cl}}{ }^{-0.015}$ (decrease in the concentration of chlorine ion in water, $\mathrm{mg} / \mathrm{L}$ ).

It is noted that with an increase in the content of chlorine ions in the solution, the redox potential increases. However, a decrease in $\mathrm{pH}$ was observed due to the influence of the chlorine ion on the concentration distribution of dissolved gases, cations, and anions in water at $\mathrm{T}_{\mathrm{H} 2 \mathrm{O}}=288 \mathrm{~K}, \mathrm{P}=0.1 \mathrm{MPa}$ (Tables 2-4, Fig. 5). Values of $\mathrm{pH}$, Eh, TDS, solution density calculated by the model are consistent with the experimental results. The total weight percent of the phase (liquid, gas, solid) in all calculations was $100 \%$, i.e. the balance is in place.

The concentration distribution of anions was studied: $\mathrm{NO}_{2}^{-}, \mathrm{NO}_{3}^{-}, \mathrm{SO}_{4}^{2-}, \mathrm{CO}_{3}^{2-} \mathrm{HCO}_{3}^{-}, \mathrm{OH}^{-}$, cations: $\mathrm{H}^{+}, \mathrm{K}^{+}, \mathrm{Na}^{+}, \mathrm{Ca}^{2+}, \mathrm{Mg}^{2+}$ and dissolved gases $\mathrm{CO}_{2}, \mathrm{O}_{2}$ (Tables 2-4) at different concentrations of chlorine ion 
Table 2. The influence of the chlorine ion on the concentration distribution of anions in water. $\mathrm{T}_{\mathrm{H} 2 \mathrm{O}}=288 \mathrm{~K}, \mathrm{P}=0.1 \mathrm{MPa}$.

\begin{tabular}{|c|c|c|c|c|c|c|}
\hline \multicolumn{7}{|c|}{ Concentration, $\mathrm{mg} / \mathrm{L}$} \\
\hline $\mathrm{Cl}$ & $\mathrm{NO}_{2}^{-}$ & $\mathrm{NO}_{3}^{-}$ & $\mathrm{SO}_{4}^{2-}$ & $\mathrm{CO}_{3}^{2-}$ & $\mathrm{HCO}_{3}^{-}$ & $\mathrm{OH}^{-}$ \\
\hline 11,40 & $0.25 \cdot 10^{-12}$ & $5.98 \cdot 10^{-12}$ & 27.00 & $0.2 \cdot 10^{-3}$ & 68.70 & $0.51 \cdot 10^{-5}$ \\
\hline 16,80 & $0.14 \cdot 10^{-12}$ & $5.98 \cdot 10^{-12}$ & 27.00 & $0.13 \cdot 10^{-3}$ & 56.10 & $0.42 \cdot 10^{-5}$ \\
\hline 33,40 & $0.09 \cdot 10^{-12}$ & $5.98 \cdot 10^{-12}$ & 27.00 & $0.09 \cdot 10^{-4}$ & 14.90 & $0.12 \cdot 10^{-5}$ \\
\hline 49,7 & $0.07 \cdot 10^{-12}$ & $5.98 \cdot 10^{-12}$ & 25.80 & $0.06 \cdot 10^{-6}$ & 1.11 & $0.09 \cdot 10^{-6}$ \\
\hline 66,7 & $0.06 \cdot 10^{-12}$ & $5.98 \cdot 10^{-12}$ & 24.30 & $0.01 \cdot 10^{-6}$ & 0.45 & $0.04 \cdot 10^{-6}$ \\
\hline 83,40 & $0.05 \cdot 10^{-12}$ & $5.98 \cdot 10^{-12}$ & 23.00 & $0.40 \cdot 10^{-8}$ & 0.27 & $0.02 \cdot 10^{-6}$ \\
\hline 100,0 & $0.05 \cdot 10^{-12}$ & $5.98 \cdot 10^{-12}$ & 21.80 & $0.20 \cdot 10^{-8}$ & 0.18 & $0.02 \cdot 10^{-6}$ \\
\hline 117,0 & $0.05 \cdot 10^{-12}$ & $5.98 \cdot 10^{-12}$ & 20.80 & $0.12 \cdot 10^{-8}$ & 0.14 & $0.15 \cdot 10^{-7}$ \\
\hline
\end{tabular}

Table 3. The influence of the chlorine ion on the concentration distribution of cations in water at $\mathrm{T}_{\mathrm{H} 2 \mathrm{O}}=288 \mathrm{~K}, \mathrm{P}=0.1 \mathrm{MPa}$.

\begin{tabular}{|c|c|c|c|c|c|}
\hline \multicolumn{7}{|c|}{ Concentration, $m g / L$} \\
\hline$C l$ & $H^{+}$ & $K^{+}$ & $N^{+}$ & $\mathrm{Ca}^{2+}$ & 4.42 \\
\hline 11.40 & $1.83 \cdot 10^{-2}$ & 0.73 & 13.70 & 14.30 & 4.42 \\
\hline 16.80 & $2.21 \cdot 10^{-2}$ & 0.73 & 13.70 & 14.30 & 4.42 \\
\hline 33.40 & $7.87 \cdot 10^{-2}$ & 0.73 & 13.70 & 14.03 & 4.42 \\
\hline 50.10 & 1.01 & 0.73 & 13.70 & 14.03 & 4.42 \\
\hline 66.7 & 2.36 & 0.73 & 13.70 & 14.03 & 4.42 \\
\hline 83.40 & 3.73 & 0.73 & 13.70 & 14.03 & 4.03 \\
\hline 100.0 & 5.11 & 0.73 & 13.70 & 14.03 & 4.42 \\
\hline 117.0 & 6.50 & 0.73 & 13.70 & 14.03 & 4.42 \\
\hline
\end{tabular}

in solution (from 11.40 to $117 \mathrm{mg} / \mathrm{L}$ ). It was noted that with a change in the concentration of the chlorine ion in the solution, the carbon concentration decreased from 27.46 to $0.05 \mathrm{mg} / \mathrm{L}$, and oxygen from 172.7 to

Table 4. The influence of the chlorine ion on the concentration distribution of dissolved gases in the water at $\mathrm{T}_{\mathrm{H} 2 \mathrm{O}}=288 \mathrm{~K}$, $\mathrm{P}=0.1 \mathrm{MPa}$.

\begin{tabular}{|c|c|c|}
\hline \multicolumn{3}{|c|}{ Concentration, $\mathrm{mg} / \mathrm{L}$} \\
\hline $\mathrm{Cl}$ & $\mathrm{CO}_{2}$ & $\mathrm{O}_{2}$ \\
\hline 11.40 & 98.50 & 0.91 \\
\hline 16.80 & 96.38 & 3.03 \\
\hline 33.40 & 92.23 & 7.17 \\
\hline 50.10 & 88.43 & 10.96 \\
\hline 66.7 & 88.24 & 15.14 \\
\hline 83.40 & 80.21 & 19.17 \\
\hline 100.0 & 76.35 & 23.02 \\
\hline 117.0 & 72.7 & 26.66 \\
\hline
\end{tabular}

94.21 $\mathrm{mg} / \mathrm{L}$. At the same time, the hydrogen concentration increased from 2.33 to $6.71 \mathrm{mg} / \mathrm{L}$, respectively, the $\mathrm{pH}$ of the solution decreased from 4.78 to 1.18 (Fig. 4), and the total dissolved solids in the solution (TDS) increased and ranged from 367.34 to $541.29 \mathrm{mg} / \mathrm{L}$.

Based on the data obtained, it was concluded for the first time that the chlorine ion mainly affects the content of carbon, oxygen, and hydrogen-containing components and particles in an aqueous solution (Tables 2-4). It is shown that with an increase in the chlorine ion content of in the model water, the redox potential $(\mathrm{Eh}>0)$ of the $\mathrm{NaCl}-\mathrm{H}_{2} 0$ system increases and remains positive. Consequently, the concentration of anions such as nitrite, sulfate, bicarbonate, and hydroxyl decreases. However, the concentration of cations: $\mathrm{H}^{+}, \mathrm{CaCl}^{+}, \mathrm{MgCl}^{+}$, and components such as $\mathrm{O}_{2}$, $\mathrm{N}_{2}, \mathrm{HCl}, \mathrm{HClO}$ increases. The concentration of ions of nitrate, calcium, magnesium, potassium, and sodium remains constant. With an increase in the concentration of chlorine ions in the solution, the content of $\mathrm{CaCl}^{+}$, $\mathrm{MgCl}^{+}, \mathrm{HCl}, \mathrm{HClO}$ changed (Fig. 4). It was found that sodium chloride does not form ion pairs in water, 


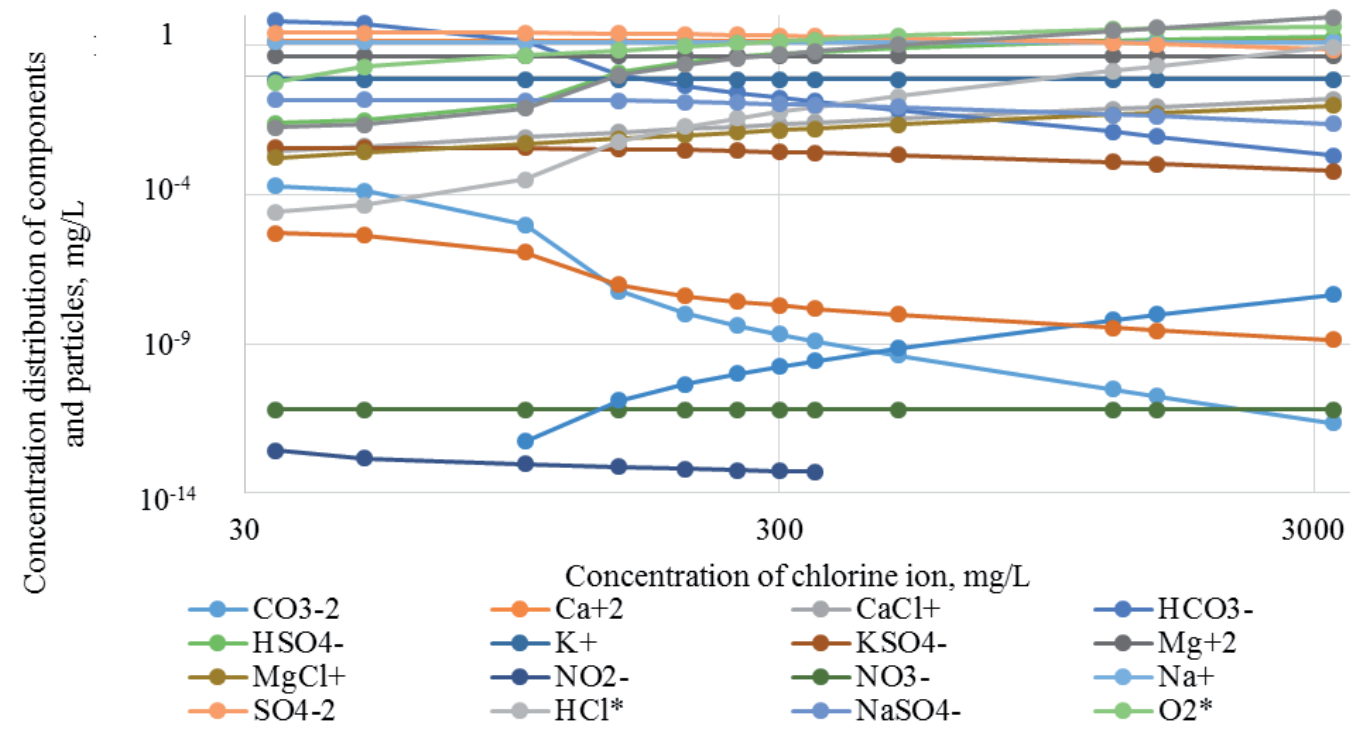

Fig. 5. Dependences of the concentration distribution of components and particles in the sodium chloride-water system on the content of chlorine-ion in the solution. $\mathrm{T}=288.15 \mathrm{~K}$.

but the chlorine ion exists as $\mathrm{Cl}^{-}$anions. Calcium and magnesium cations were found in the form of ion pairs such as $\mathrm{CaCl}^{+}, \mathrm{CaOH}^{+}, \mathrm{MgCl}^{+}, \mathrm{Mg}\left(\mathrm{HCO}_{3}\right)^{+}$(Table 3, Fig. 5).

Sodium chloride is widely used in winter as an anti-ice reagent that does not form ion pairs in water, therefore, technogenic chlorine ion $\left(\mathrm{Cl}^{-}\right)$has a high migration ability, i.e. practically not sorbed by various suspensions. The main method for determining the salinity of a solution is the argentometric method based on this principle for silver nitrate [42]. When determining the concentration of chlorides by the argentometric method, it is necessary to determine the content of all halogens present in the water. The method requires the automation of experimental studies, and silver nitrate, an expensive chemical, is used as the

Table 5. The concentration of chlorine ion in water and the $\mathrm{pH}$ of solution. $\mathrm{C}_{\mathrm{Na}}{ }^{+}=41.24 \mathrm{mg} / \mathrm{L}, \mathrm{C}_{\mathrm{Cl}}=24.26 \mathrm{mg} / \mathrm{L}, \mathrm{pH}=7.68$ (experimental values), $\mathrm{T}=278-308 \mathrm{~K}$.

\begin{tabular}{|c|c|c|c|}
\hline Increasing of $\mathrm{C}_{C l} 10^{-3}, \mathrm{mg} / \mathrm{L}$ & $p H(T=278-308 K)$ & $C_{C l} 10^{-3}, \mathrm{mg} / \mathrm{L}$ & $p H(T=278-308 K)$ \\
\hline 0.034 & $4.72-4.91$ & 3 & $1.17-1.18$ \\
\hline 0.050 & $4.64-4.84$ & 5 & 0.99-0.99 \\
\hline 0.1 & $4.09-4.27$ & 10 & $0.74-0.74$ \\
\hline 0.15 & $3.03-3.05$ & 30 & $0.40-0.38$ \\
\hline 0.2 & $2.67-2.69$ & 50 & $0.28-0.25$ \\
\hline 0.25 & $2.47-2.49$ & 100 & $0.19-0.14$ \\
\hline 0.3 & $2.34-2.35$ & 200 & $0.14-0.07$ \\
\hline 0.35 & $2.24-2.25$ & 500 & $0.1-0.04$ \\
\hline 0.5 & $2.03-2.04$ & 1000 & $0.09-0.03$ \\
\hline 1 & $1.58-1.58$ & - & - \\
\hline Decreasing of $\mathrm{C}_{\mathrm{Cl}} 10^{-3}, \mathrm{mg} / \mathrm{L}$ & $p H(T=278-308 K)$ & & \\
\hline 0.024 & 7.94-7.48 (calc.) & - & - \\
\hline 0.014 & $8.49-7.97$ & - & - \\
\hline 0.004 & $8.81-8.30$ & - & - \\
\hline 0.0004 & $8.85-8.35$ & - & - \\
\hline 0.00004 & $8.87-8.36$ & - & - \\
\hline
\end{tabular}




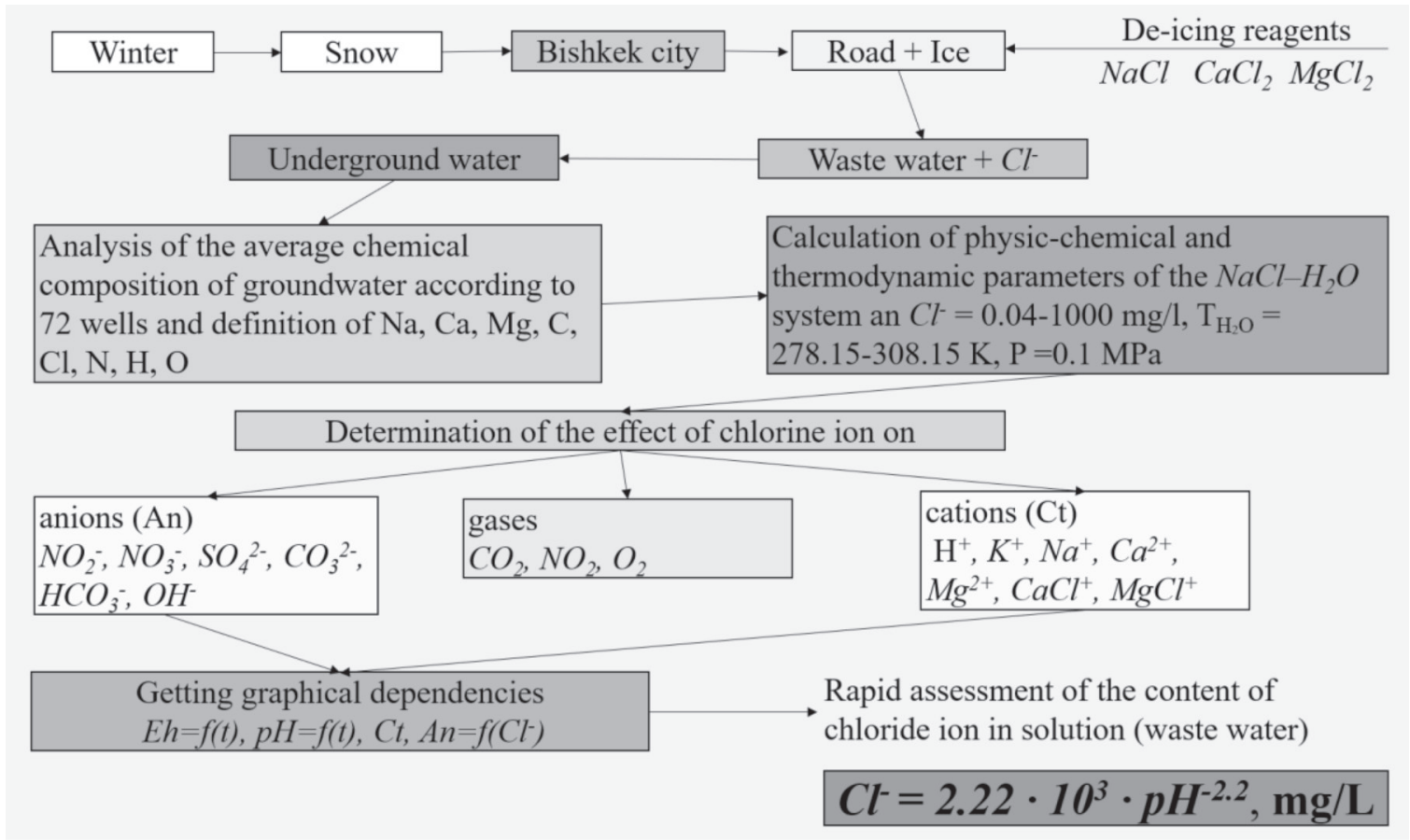

Fig. 6. Scheme of rapid assessment of the content of technogenic chlorine ion in water of reservoirs by $\mathrm{pH}$.

main reagent. In such situations, an express assessment of the concentration of technogenic chlorine ion in the water of reservoirs by the $\mathrm{pH}$ of the solution is effective (Table 5). Taking into account the distribution of the concentrations of elements $(\mathrm{Na}, \mathrm{Ca}, \mathrm{Mg}, \mathrm{C}, \mathrm{Cl}, \mathrm{S}, \mathrm{N}, \mathrm{K}$, $\mathrm{H}, \mathrm{O})$, components and particles $(\mathrm{An}-, \mathrm{Kt}+$ ) contained in $1 \mathrm{~kg}$ of an aqueous solution, diagram and an empirical equation was obtained (Fig. 6). It was also noted that complex cations and anions are formed in an aqueous solution with a strong adsorption capacity for various suspensions. Accordingly, it is required to calculate the equilibrium concentrations of such complex particles as $\mathrm{CaOH}^{+}, \mathrm{Mg}\left(\mathrm{HCO}_{3}\right)^{+}$, etc.

Table 5 shows that the experimental $\mathrm{pH}$ value coincides with the calculated $\mathrm{pH}$ values, for example, at $\mathrm{C}_{\mathrm{Cl}}{ }^{-}=24.26 \mathrm{mg} / \mathrm{L}, \mathrm{pH}=7.68$ (experimental) and calculated $\mathrm{pH}=7.94-7.48$ (calculated) in the temperature range from $278 \mathrm{~K}$ to $308 \mathrm{~K}$.

The results of studies carried out in the $\mathrm{NaCl}-\mathrm{H}_{2} \mathrm{O}$ system made it possible to draw up a scheme (Fig. 6), showing the effect of technogenic chloride not only on environmental components but primarily on the concentration distribution of dissolved gases, anions $\left(\mathrm{An}^{-}\right)$, cations $\left(\mathrm{Kt}^{+}\right)$in the water itself, as well as to obtain a generalized equation:

$$
\mathrm{C}_{\mathrm{Cl}}=2.22 * 10^{3} * \mathrm{pH}^{-2.2}, \mathrm{mg} / \mathrm{L} \text {. }
$$

The obtained empirical equation:

$$
\mathrm{C}_{\mathrm{Cl}}=2.22 * 10^{3 *} \mathrm{pH}^{-2.2}, \mathrm{mg} / \mathrm{L}
$$

allows an express assessment of the content of chlorine ion in water of reservoirs by means of experimental determination of $\mathrm{pH}$ in the range of changes in the concentration of chlorides from 50 to $1000 \mathrm{mg}$ and liquid temperatures from 278 to $308 \mathrm{~K}$. Experimental and calculated $\mathrm{pH}$ values are in satisfactory agreement. The relative error does not exceed 5\% (Table 5).

The determination of chlorine ions in groundwater by hydrogen index is carried out for the first time. Most of the studies focused on the determination of groundwater salinity by laboratory conditions using argentometric methods [42] or ionic conductivity methods for determining the salinity [3, 7, 10-15, 17, 21]. However, these methods require expensive reactive and instrumental tools. Therefore, a simple method has been proposed for determining the concentration of chloride ions using an empirical formula based on $\mathrm{pH}$. Our calculation methods showed that certain concentrations of chlorides from foreign studies correlate with our work [10, 21, 43].

\section{Conclusions}

The anthropogenic load of sodium chloride used in winter on the roads of Bishkek was determined. The chemical matrix of groundwater in Bishkek and its environs was compiled on the basis of experimental data from 72 wells, which are the main source of water supply in Bishkek. Thermodynamic modeling of the sodium chloride-water system was carried out at the minimum of Gibbs energy. Thus, the physicochemical and thermodynamic parameters of the model aqueous system $\mathrm{NaCl}-\mathrm{H}_{2} \mathrm{O}$ were calculated at a wide temperature range. The $\mathrm{Eh}$ and $\mathrm{pH}$ values were calculated over a wide range of water temperature 
variations. It was shown that with an increase in the content of technogenic chlorine ion in the model water, the redox potential (Eh) of the $\mathrm{NaCl}-\mathrm{H}_{2} 0$ system was positive. The concentration distribution of components and charged particles in solution was established for the first time: $\mathrm{CO}_{3}^{-2}, \mathrm{Ca}_{2}^{+}, \mathrm{CaCl}^{+}, \mathrm{Cl}^{-}$, $\mathrm{HSO}_{4}^{-}, \mathrm{K}^{+}, \mathrm{KSO}_{4}, \mathrm{Mg}_{2}^{+}, \mathrm{MgCl}^{+}, \mathrm{NO}_{2}^{-}, \mathrm{NO}_{3}^{-}, \mathrm{Na}^{+}$, $\mathrm{SO}_{4}^{-2}, \mathrm{HCO}_{3}^{-}, \mathrm{NaSO}_{4}, \mathrm{OH}^{-}, \mathrm{H}^{+}$, and also noted the selective effect of the chlorine ion on the cations and anions of the water. The results of the study made it possible to carry out an express assessment of the quantitative content of technogenic chlorine ion in the water of reservoirs by experimentally determining the $\mathrm{pH}$ in the range of changes in chloride concentration from 50 to $1000 \mathrm{mg}$ and liquid temperature from 278 to $308 \mathrm{~K}$. The obtained scheme for evaluating the chlorine ion in water and the empirical equation based on it are useful in analytical studies of water.

\section{Conflict of Interest}

The authors declare no conflict of interest.

\section{References}

1. ARZHAKHUNINA S.P. Production technologies icing materials based on anhydrous calcium chloride. Construction Materials, 2, 5, 2011 [In Russian].

2. KOGER L.M. Calcium Chloride, Practical Necrotizing Agent. Journal of the American Association of Bovine Practitioners (USA), 12, 118, 1977.

3. FAY L. SHI X. Laboratory investigation of performance and impacts of snow and ice control chemicals for winter road service. Cold Regions Engineering, 25 (3), 89, 2011.

4. HUNT M. HERRON E., GREEN L. Chlorides in Fresh Water. URIWW 4, 2012.

5. Calcium Chloride SIDS Initial Assessment Profile, UNEP Publications, SIAM 15, Boston, 22-25 October, 11, 2002.

6. HOSSEINI F., HOSSAIN S.M.K., FU L. Bio-based materials for improving winter pavement friction. Canadian Journal of Civil Engineering. 44 (2), 99, 2017.

7. KELLY W.R. Long-term trends in chloride concentrations in shallow aquifers near Chicago. Ground Water, 46 (5), 772, 2008.

8. MAYER T., ROCHFORT Q., BORGMANN U., SNODGRASS W. Geochemistry and toxicity of sediment porewater in a salt-impacted urban stormwater detention pond. Environmental Pollution, 156 (1), 143, 2008.

9. KAUSHAL S.S., COLE-NEAL C.L., FAIRCHILD J.F. GROFFMAN P.M., LIKENS G. E., BELT K.T., STACK W.P., KELLY V.R., BAND L.E., FISHER G.T. Increased salinization of fresh water in the northeastern United States. Proceedings Of The National Academy Of Sciences Of The USA, 102 (38), 13517, 2005.

10. KORETSKY C.M., MACLEOD A., SIBERT R.J., SNYDER C. Redox Stratification and Salinization of Three Kettle Lakes in Southwest Michigan, USA. Water Air and Soil Pollution, 223 (3), 1415, 2012.

11. LIKENS G.E. BUSO D.C. Salinization of Mirror Lake by Road. Water Air and Soil Pollution. 205 (1-4) 205, 2010.
12. AGHAZADEH N., NOJAVAN M., MOGADDAM A.A. Effects of road-deicing salt $(\mathrm{NaCl})$ and saline water on water quality in the Urmia area, northwest of Iran. Arabian Journal of Geosciences, 5 (4), 565, 2012.

13. RAMAKRISHNA D.M., VIRARAGHAVAN T. Environmental impact of chemical deicers-A REVIEW. Water Air and Soil Pollution, 166 (4), 49, 2005.

14. DUGAN H.A., HELMUELLER G. Ice formation and the risk of chloride toxicity in shallow wetlands and lakes. Limnology and Oceanography Letters, 2 (5), 150, 2017.

15. ROSSI R.J., BAIN D.J., ELLIOTT E.M., DIVERS M., O'NEILL B. Hillslope soil water flow paths and the dynamics of roadside soil cation pools influenced by road deicers. Hydrological Processes, 31 (1), 177, 2017.

16. ALLERT A.L., COLE-NEAL C.L., FAIRCHILD J.F. Toxicity of chloride under winter low-flow conditions in an urban watershed in Central Missouri, USA. Bulletin Of Environmental Contamination and Toxicology, 89 (2), 296, 2012.

17. SIBERT R.J., KORETSKY C.M., WYMAN D.A. Cultural meromixis: Effects of road salt on the chemical stratification of an urban kettle lake. Chem. Geology, 395, 126, 2015.

18. MAHROSH U., ROSSELAND B.O., SALBU B., TEIEN H.C. Single and multiple stressor effect of road deicers and $\mathrm{Cu}$ on Atlantic salmon (Salmo salar) alevins from hatching till swim-up. Journal of Environmental Sciences, 66, 368, 2018.

19. SCHULER M.S., HINTZ W.D., JONES D.K., LIND L.A., MATTES B.M., STOLER A.B., SUDOL K.A., RELYEA R.A. How common road salts and organic additives alter freshwater food webs:in search of safer alternatives. Applied Ecology, 54 (5), 1353, 2017.

20. HOPKINS G.R., FRENCH S.S., JR. BRODIE E.D. Potential for local adaptation in response to an anthropogenic agent of selection: effects of roaddeicing salts on amphibian embryonic survival and development. Evolutionary Applications, 6 (2), 384, 2013.

21. DUPUIS D., SPRAGUE E., DOCHERTY K.M., KORETSKY C.M. The influence of road salt on seasonal mixing, redox stratification and methane concentrations in urban kettle lakes. Science of the Total Environment, 661, 514, 2019.

22. VAN METER R.J., SWAN C.M., SNODGRASS J.W. Salinization alters ecosystem structure in urban stormwater detention ponds. Urban Ecosystems, 14 (4), 723, 2011.

23. JONES D.K., MATTES B.M., HINTZ W.D., SCHULER M.S., STOLER A.B., LIND L.A., COOPER R. O., RELYEA R.A. Investigation of road salts and biotic stressors on freshwater wetland communities. Environmental Pollution, 221, 159, 2017.

24. BAEK M.J., YOON T.J., KIM D.G., LEE C.Y., CHO K.B., BAE Y.J. Effects of road deicer runoff on benthic macroinvertebrate communities in Korean freshwaters with toxicity tests of calcium chloride $\left(\mathrm{CaCl}_{2}\right)$. Water Air \& Soil Pollut., 225 (6), 1961, 2014.

25. KOTALIK C.J., CLEMENTS W.H., CADMUS P. Effects of magnesium chloride road deicer on montane stream benthic communities. Hydrobiologia, 799 (1), 193, 2017.

26. SOUNDARARAJAN P., MANIVANNAN A., KO C.H., PARK J.E., JEONG B.R. Evaluation of relative toxicity caused by deicing agents on photosynthesis, redox homeostasis, and the osmoregulatory system in creepertype plants. Environment and Biotechnology, 60 (2), 175, 2019. 
27. SCHULER M.S., RELYEA R.A. Road salt and organic additives affect mosquito growth and survival: an emerging problem in wetlands. OIKOS, 127 (6), 866, 2018.

28. GALUSZKA A., MIGASZEWSKI Z.M., PODLASKI R., DOLEGOWSKA S., MICHALIK A. The influence of chloride deicers on mineral nutrition and the health status of roadside trees in the city of Kielce, Poland. Environmental Monitoring and Assessment., 176 (4), 451, 2011.

29. KIM S-Y., KORETSKY C. Effects of road salt deicers on sediment biogeochemistry. Biogeochemistry, 112 (1), 343, 2013.

30. BAUMGÄRTEL S., ROHN J., LUO J. Experimental study of road deicing by using the urban groundwater under the climatic condition of Nuremberg city, Germany. SN Appl. Sci. 2, 5372020

31. TERRY L.G., CONAWAY K., REBAR J., Graettinger A.J. Alternative Deicers for Winter Road Maintenance - A Review. Water Air Soil Pollut, 231, 394, 2020.

32. DIKIKH A.N. Tien Shan modern glaciation regime. Frunze, 159, 1982 [In Russian].

33. RAMAZAN M.E. Some features of the hydrological regime and hydraulic characteristics of the rivers of Kyrgyzstan, Frunze, 91, 1960.

34. KARAMOLDOEV J.J. Formation of river flow in Kyrgyzstan during dry periods and its rational use. Bishkek, 159. 2002 [In Russian].

35. DIKIKH A.N. Study of the regime of glaciation, ice resources and glacial runoff of the Tien Shan mountain system. Moskva, 32, 1998 [In Russian].
36. KOJOBAEV K.A., IZAKOV J.B. Some statistics on ecogeochemistry of Chu valley groundwater. Proceeding Of The ICOEST, 115, 2013.

37. DEMIREL Z., KOCABAYEV K., KEMELOV K., MOLDOGAZIEVA G., KASIEV A. Researching groundwater of Bishkek city by geographical information system, International environmental symposium series; Bishkek, Kyrgyzstan, 2009.

38. DEMIREL Z., KOCABAYEV K., KEMELOV K., MOLDOGAZIEVA G., KASIEV Simulation of groundwater of Bishkek city, International environmental symposium series; Bishkek, Kyrgyzstan, 2009.

39. Main provisions of the National Strategy for the Use of Water Resources of the Kyrgyz Republic. Bishkek, 24, 2009 [In Russian]

40. KARPOV I.K., CHUDNENKO K.V., KULIK D.A., BYCHINSKII V.A. The convex programming minimization of five thermodynamic potential other than Gibbs energy in geochemical modeling. Amer. J. Sci., 302, 281,2002

41. KARPOV I.K., CHUDNENKO K.V., KULIK D.A. Modeling chemical mass transfer in geochemical processes: Thermodynamic relations, conditions of equilibria, and numerical algorithms. Amer. J. Sci., 297, 767, 1997.

42. ZHIDKOVA L., GROMOVA N.G., WULFSON N.D. Argentometric determination of chlorides in waters. Sosnovyy Bor, 1999 [In Russian].

43. DAILEY K.R., WELCH K. A., LYONS W.B. Evaluating the influence of road salt on water quality of Ohio rivers over time. Applied Geochemistry, 47, 25, 2014. 